\title{
Numerical Simulation of CulnSe 2 (CIS) Thin Film Solar Cell with (ZnO, ZnO:F) Buffer Layers
}

\author{
T. Belal ${ }^{1}$, R. Tala-Ighil Zair ${ }^{2,}$, F. Ghezal ${ }^{2}$ \\ ${ }^{1}$ Department of Physics, Laboratory-N Body \& Structure of Matter, Algiers, Algeria \\ ${ }^{2}$ University M'hamed Bougara Boumerdes, URMPE Research Unit, Institute of Electrical \& Electronic Engineering, Boumerdes, Algeria
}

\section{Email address:}

taharbelal@yahoo.fr (T. Belal), t_razika@hotmail.com (R. Tala-Ighil Z.), ghezalfathi@yahoo.fr (F. Ghezal)

${ }^{*}$ Corresponding author

\section{To cite this article:}

T. Belal, R. Tala-Ighil Zair, F. Ghezal. Numerical Simulation of CuInSe 2 (CIS) Thin Film Solar Cell with (ZnO, ZnO:F) Buffer Layers. American Journal of Nanosciences. Vol. 3, No. 3, 2017, pp. 53-58. doi: 10.11648/j.ajn.20170303.14

Received: April 8, 2017; Accepted: August 14, 2017; Published: October 23, 2017

\begin{abstract}
This study focuses on the solar cells based on CIS simulation with buffer layer zinc oxide (ZnO) and fluorinedoped zinc oxide ( $\mathrm{ZnO}: \mathrm{F}) . \mathrm{ZnO}$ is a multifunctional material with several applications in electronics and photovoltaics, with multiple possibilities of synthesis involve inexpensive methods. $\mathrm{ZnO}(\mathrm{ZnO}: \mathrm{F})$ is a prominent candidate to be an alternative buffer layer to so-called toxic cadmium sulphide (CdS) in CIS based solar cells. A promising result has been achieved with an efficiency of $22 \%$ with $\mathrm{Voc}=0.565 \mathrm{~V}, \mathrm{Jsc}=45 \mathrm{~mA} / \mathrm{cm}^{2}$ and fill factor $=82 \%$ by using $\mathrm{ZnO}(\mathrm{ZnO}$ :F) as a buffer layer. It is also found that the high efficiency of CIS absorber layer thickness is between $1500 \mathrm{~nm}$ and $2000 \mathrm{~nm}$. Our results are in good agreement with those reported in the literature from experiments.
\end{abstract}

Keywords: CIS, ZnO, ZnO:F, SCAPS, Buffer Layer

\section{Introduction}

The primary energy source choice determines the political effort, economic and technology required for the extraction, processing, transportation and distribution. Not to mention the technical use, solar energy is becoming one of the primary energy sources replacing fossil fuels due to its abundance and large factories have achieved superb economies of scale that have enabled the modules manufacture with power conversion efficiency in the range of $14-21 \%$ based on silicon ( $\mathrm{Si}$ ), cadmium telluride (CdTe) and copper indium gallium diselenide (CIGS) at a cost less than $\$ 1 / \mathrm{W}[1,2]$. Despite this progress, photovoltaics produce less than one percent of the world's electricity and there is a strong desire to both continue reducing costs to less than $\$ 0.5 / \mathrm{W}$ while also raising the power conversion efficiency above $25 \%$ following DOE report [3].

A $\mathrm{ZnO}$ buffer layer is a prominent candidate to be an alternative buffer layer to so-called toxic cadmium sulphide $(\mathrm{CdS})$ in CIS based solar cells. In this study, buffer layer parameters layer thickness and buffer layer band gap have been investigated by Solar Cell Capacitance Simulator
(SCAPS) to find out the higher conversion efficiency.

The purpose is to demonstrate that SCAPS can handle such complicated material properties, and to illustrate how these properties influence the metastable cell behaviour as developed by Burgelman et al. [4]

A buffer layer is introduced in between the p-type CIS absorber and TCO layer because experiments show superior performance of cell with a buffer layer compared with a cell without it. $\mathrm{ZnO}(\mathrm{ZnO}: \mathrm{F})$ is used as a buffer layer for two main objectives, to provide structural stability to the device and to fix the electrostatic conditions inside the absorber layer. $\mathrm{ZnO}$ ( $\mathrm{ZnO}: \mathrm{F}$ ) is a direct band gap semiconductor with band gap of $3.30 \mathrm{eV}(3.20 \mathrm{eV})$. CIS is used as the absorber layer which is the most important layer in the PV device. CuInSe ${ }_{2}$ is a compound semiconductor exhibiting chalcopyrite crystal structure having large absorption-coefficient $\left(\alpha \sim 10^{5} \mathrm{~cm}^{-1}\right)$ as mentioned in reference [5]: Back contact performs the function of collecting carriers from the absorber and delivering it to an external load. CIS solar cells having Mo back contact gives superior performance compared with other metals. Metals to be used as back contact must have low resistivity and should not hinder the majority carriers and holes flow. The back contact is also defined by its work 
function and reflectivity at the contact-semiconductor interface. The use of soda lime glass as glass substrate has several benefits, including corrosion resistance, low price and contribution to the molecular oxygen disassociation.

However, according to Malm et al. [6], at high temperature the glass substrate gets softened and ultimately gets bend and distorted. Thin-film $\mathrm{CuInSe}_{2}$ (CIS) solar cells have major potential as a source of low-cost, high-efficiency solar electricity. The first design principle to consider when making tandem solar cells is choosing the right band gaps in order to optimize the solar spectrum harvesting. The equivalent of 0.5 to $1 \mathrm{~kg}$ per $\mathrm{m}^{2}$ of silicon is needed to achieve a conventional photovoltaic module, while the $\mathrm{CuInSe}_{2}$ only the copper amount of 1.5 to $4 \mathrm{~g}, 3-9 \mathrm{~g}$ of indium and 7-20 $\mathrm{g}$ selenium is sufficient to achieve the equivalent of the silicon.

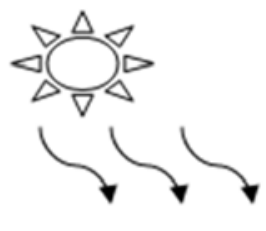

Ni/Al

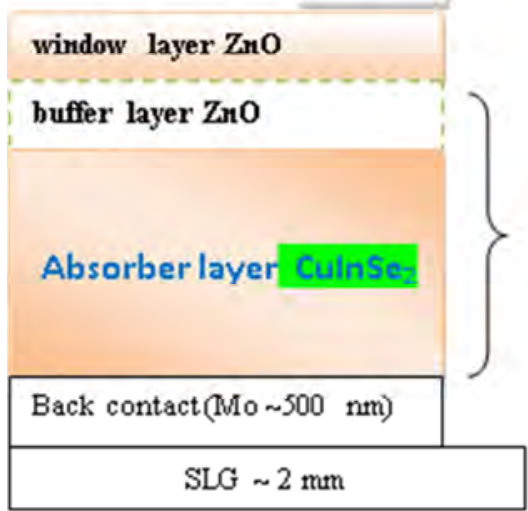

\section{Numerical Simulation}

The structures were studied in the AM1.5 solar spectrum, with $\mathrm{P}_{0}=100 \mathrm{~mW} / \mathrm{cm}^{2}$ and $\mathrm{T}=300 \mathrm{~K}$. Photovoltaic parameters measurements were performed in the case of zero series resistance and an infinitely large shunt resistance. The various parameters' optimization of the cell of interest is obtained according to the maximum simulation power, by varying every time a single parameter for each layer constituting the cell. The investigated parameters are the thickness and doping. In our study, we use a solar cell heterojunction composed of the following: $\mathrm{ZnO}$ ( $\mathrm{ZnO}: \mathrm{F}) /$ CIS. The simplified heterostructure diagram is shown in Figure 1.

Figure 1. Simplified diagram of a solar cell thin-film CIS type.

The semiconductor layers (CIS absorber), $\mathrm{ZnO}$ ( $\mathrm{ZnO}: \mathrm{F}$ ) (buffer) were the subject of our study in numerical models to see their influence on the solar cell electrical performance. The CdS replacement by $\mathrm{ZnO}$ with optical window $\mathrm{ZnO}(\mathrm{F})$ of the same family has the effect to reduce the lattice mismatch between layers and to increase the cell performance and by mean of consequence the solar cell efficiency. Devices parameters used in the SCAPS simulation (Table 1 and Table 2).

Table 1. Properties of the three layers $\mathrm{ZnO}, \mathrm{ZnO}: \mathrm{F}$ and CIS.

\begin{tabular}{llll}
\hline Layer properties & ZnO [7] & ZnO:F [7] & CIS [8, 9] \\
\hline Thickness $(\mathrm{nm})$ & 50 & 50 & 2000 \\
dielectric constant & 10 & 10 & 10 \\
Electron mobility $\left(\mathrm{cm}^{2} / \mathrm{V} . \mathrm{s}\right)$ & 50 & 50 & 100 \\
Hole mobility $\left(\mathrm{cm}^{2} / \mathrm{V} . \mathrm{s}\right)$ & 20 & 20 & 25 \\
Carrier density $\left(\mathrm{cm}^{-3}\right)$ & $5 \times 10^{17}$ & $5 \times 10^{17}$ & $10^{16}$ \\
Gap band $(\mathrm{eV})$ & 3.30 & 3.20 & 1.04 \\
$\mathrm{Nc}\left(\mathrm{cm}^{-3}\right)$ & $4 \times 10^{18}$ & $4 \times 10^{18}$ & $2.2 \times 10^{18}$ \\
$\mathrm{Nv}\left(\mathrm{cm}^{-3}\right)$ & $4 \times 10^{18}$ & $4 \times 10^{18}$ & $1.8 \times 10^{19}$ \\
Electron affinity $(\mathrm{eV})$ & 4.55 & 4.50 & 4.30 \\
\hline
\end{tabular}

Table 2. Cell properties.

\begin{tabular}{ll}
\hline Cell temperature & $\mathbf{3 0 0 K}$ \\
\hline Serie resistance Rs & $0 \Omega / \mathrm{cm}^{2}$ \\
Shunt resistance Rsh & $0 \Omega / \mathrm{cm}^{2}$ \\
Back metal contact & $0.20 \mathrm{eV}$ \\
Mo electron Work Function & $5.00 \mathrm{eV}$ \\
SRV electron & $10^{5} \mathrm{~cm} / \mathrm{s}$ \\
SRV hole & $10^{7} \mathrm{~cm} / \mathrm{s}$ \\
Ni/Al Metal Front Contact & $4.35 \mathrm{eV}$ \\
SRV electron & $10^{7} \mathrm{~cm} / \mathrm{s}$ \\
SRV hole & $10^{5} \mathrm{~cm} / \mathrm{s}$ \\
\hline
\end{tabular}

In the table 1 , the $\mathrm{ZnO}$ properties were extracted from reference [7], the CIS parameters from [8,9].

\section{Results and Discussions}

\subsection{Thickness Layer Effect ZnO (ZnO:F)}

At the beginning of the simulation, the buffer layer 
thickness has been varied from $10 \mathrm{~nm}$ to $50 \mathrm{~nm}$ to carry out the optimum electrical performance of the solar cell heterojunction. In addition, the CIS layer thickness is kept $2000 \mathrm{~nm}$ during the simulation. It has been investigated that the efficiency of the solar cell is decreasing with the $\mathrm{ZnO}$ (ZnO:F) buffer layer thickness. The highest efficiency
$20.79 \%$ is measured, when the buffer layer thickness is between $10 \mathrm{~nm}$ and $30 \mathrm{~nm}$. It can be attributed to thinner layer thickness where less photon energy will be absorbed. Moreover, the CIS layer band gap is $1.10 \mathrm{eV}$ [10]. The obtained result is shown in Figure 2.

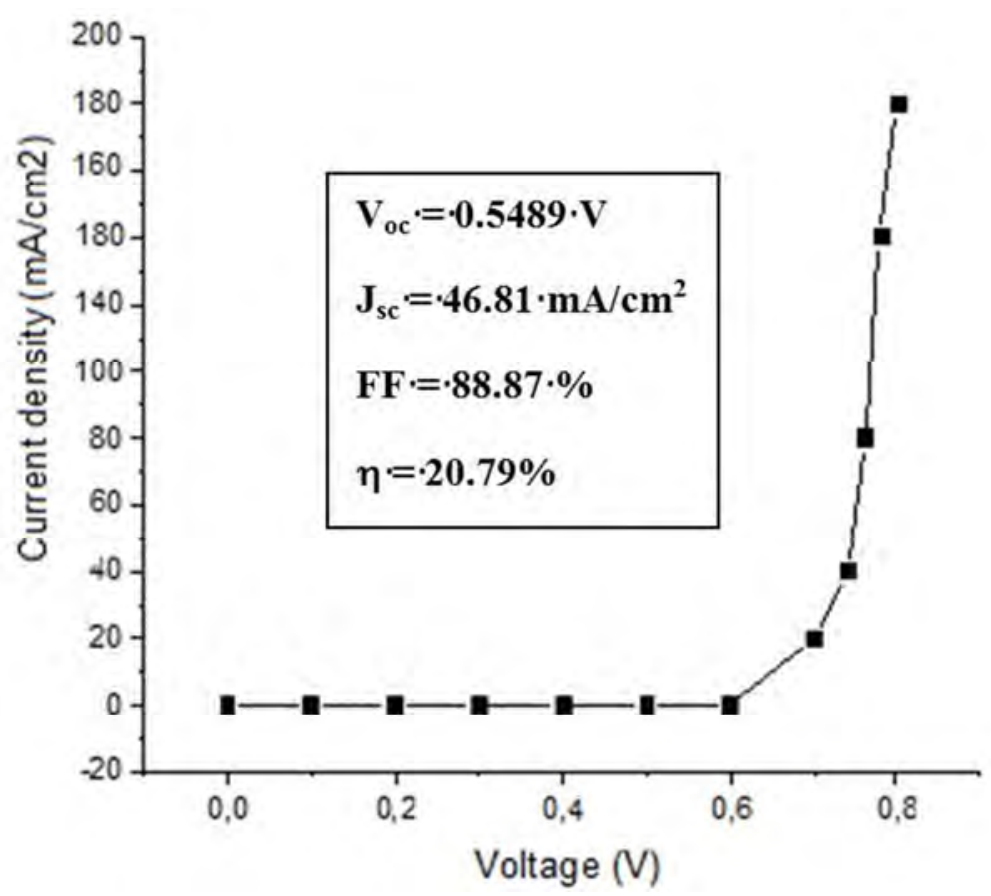

Figure 2. J-V Characteristics for ZnO:F/ZnO/CIS/Mo cells with different $\mathrm{ZnO}(\mathrm{ZnO}: F)$ buffer layer thicknesses.

\subsection{Buffer Layer ZnO (ZnO:F) Doping Influence}

A renewed interest in the study of zinc oxide thin films exists due to the simultaneous properties of low resistivity ad high transmittance besides chemical stability under strong reducing environments. despite the extensive investigations on this material, there are still some unknown points related to some dopants effect in the transport properties.

The case of fluorine doped $\mathrm{ZnO}$ thin films is an example for this. Apart from the academic interest, the fluorine doping has several potential advantages over the well-known and successful In-doping, such as low cost and abundance. More over fluorine does not introduce significant perturbation into the conduction band, due to the size compatibility of the oxygen and fluorine atoms [11].

Fluorine was expected to occupy the oxygen site in $\mathrm{ZnO}$ and hence promote the film conductivity. The buffer layer role is to ensure good electrical and optical interface properties between the CIGS absorber and the $\mathrm{ZnO}$ layers, and therefore the buffer layer plays a decisive role in the solar cell performance as mentioned by Lindahl et al. [12] The I(V) curve with $\mathrm{ZnO}$ buffer layer is shown in figure 3.

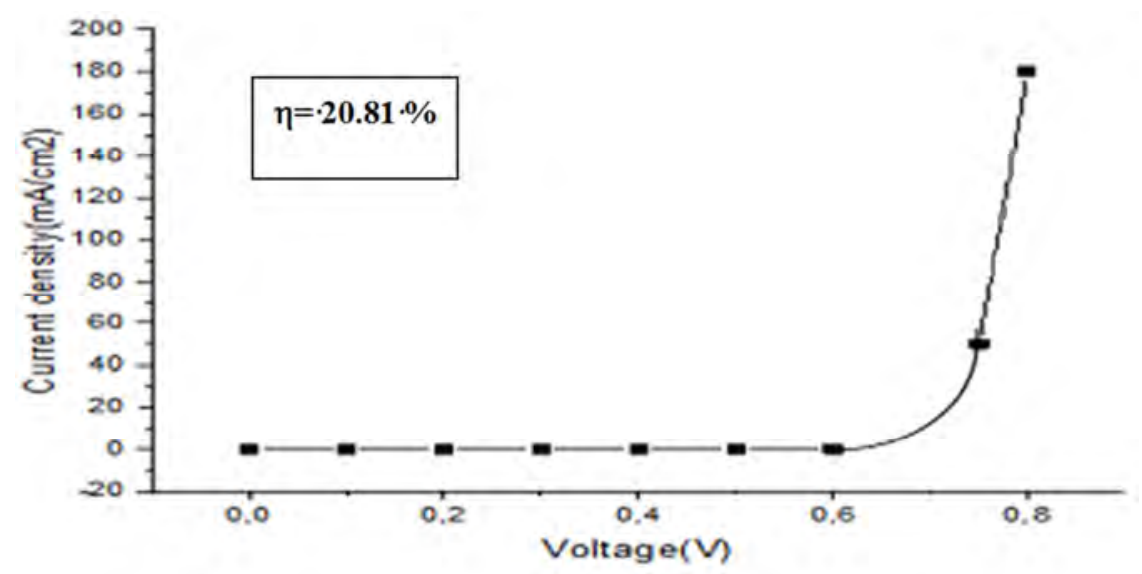

Figure 3. Influence of the doping of the buffer layer $n$ / ZnO on the JV characteristic. 
While figure 4 represents the I (V) curve with $\mathrm{ZnO}$ :F buffer layer.

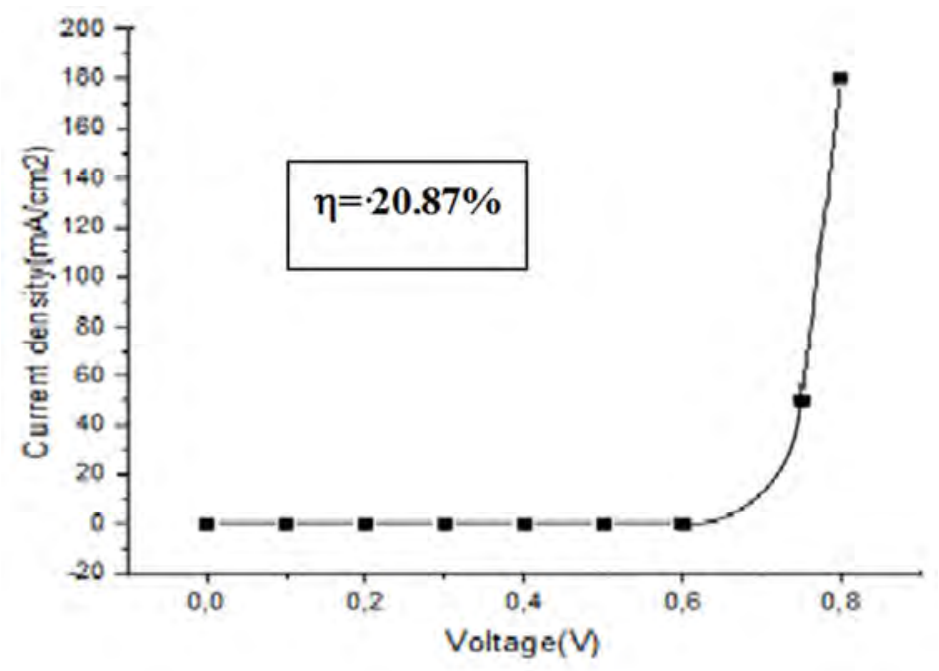

Figure 4. Influence of the doping of the buffer layer $n$ / ZnO:F on the J-V characteristic.

According to the various curves I (V), it is noted the same shape. This allows us to say that the window layer doping concentration does not influence significantly on the structure's IV characteristic. The electrical efficiency is stable to $20.81 \%(20.87 \%)$ between a doping range $5 \times 10^{16}$ to $5 \times 10^{19} \mathrm{~cm}^{-3}$ for both $\mathrm{ZnO}$ layers $(\mathrm{F}$ : $\mathrm{ZnO})$, and a small decrease in yield for the doping $10^{16} \mathrm{~cm}^{-3}$. There is a slight yield increase $0.06 \%$ with the buffer layer $\mathrm{F}$ : $\mathrm{ZnO}$.

A heavily doped n-type $\mathrm{ZnO}$ window layer is preferred for the performance improvement. This hetero-junction nature implies energy band discontinuities at the $p-n$ junction [13]

\subsection{Effect of the Absorber Layer CIS}

\subsubsection{The Absorber CIS Doping Influence}

We proceed to the change in $\mathrm{N}_{\mathrm{D}} /$ CIS from $10^{12}$ to $10^{17} \mathrm{~cm}^{-2}$. The inserted data in SCAPS software provide us the results summarized in table 3 .

Table 3. The CIS absorber doping influence.

\begin{tabular}{lll}
\hline \multirow{2}{*}{$\begin{array}{l}\text { Doping density } \mathbf{N}_{\mathbf{D} /} \mathbf{C I S} \\
\left(\mathbf{c m}^{-\mathbf{3}}\right)\end{array}$} & \multicolumn{2}{l}{ Conversion efficiency $\boldsymbol{\eta}(\%)$} \\
\cline { 2 - 3 } $10^{12}$ & ZnO Buffer layer & $\mathbf{Z n O : ~} \mathbf{F}$ Buffer layer \\
$10^{13}$ & 9.41 & 9.41 \\
$10^{14}$ & 21.46 & 23.56 \\
$10^{15}$ & 22.14 & 24.25 \\
$10^{16}$ & 22.53 & 24.66 \\
$10^{17}$ & 22.82 & 24.95 \\
\hline
\end{tabular}

\subsubsection{CIS Layer Thickness Effect}

In Figure 5, we see an efficiency increase with the absorber layer thickness with $\mathrm{ZnO}$ : $\mathrm{F}$ layer over the $\mathrm{ZnO}$ layer, which gives priority to the use $\mathrm{ZnO}$ : F layer and built a good pn junction with an acceptable range recombination between $1.5 \mu \mathrm{m}$ and $2.5 \mu \mathrm{m}$.

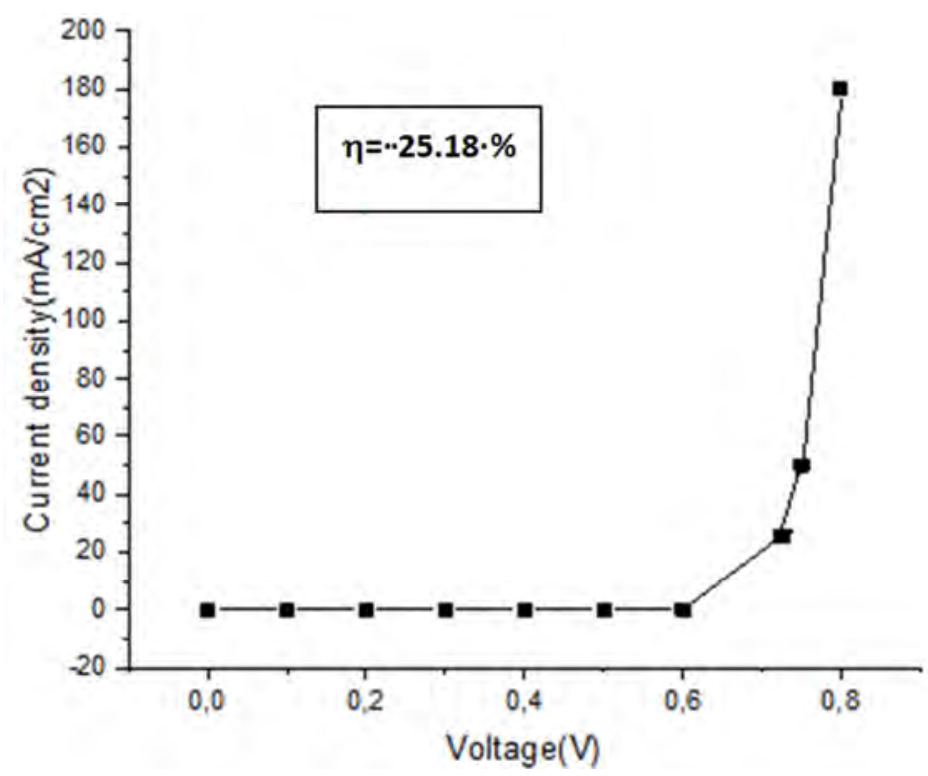

Figure 5. J-V Characteristics for ZnO:F/ZnO/CIS/Mo cells with influence of the thickness of the CIS absorber. 
Respectively $\eta(\%)=25.18 \%(23.04 \%)$. During photoexcitation, electrons and holes will be separated at the absorber/buffer interface and electrons will be transported to the buffer side. Sun et al. [14] reported that the defects in the buffer will affect the electron transport from CIS to $\mathrm{ZnO}: \mathrm{F}$ and reduce the lifetime of these electrons.

\subsection{Quantum Efficiency}

Quantum-efficiency measurements (QE) quantify the device's spectral response. QE characteristics permit to detect the current losses by reflection, incomplete collection and recombination in the different layers and are useful to optimize the solar cell performance. The interest of applying alternative buffer layers with wider band-gap values than $\mathrm{CdS}$ has to do with the potential of current generation increase particularly in the spectral region for wavelengths $<550 \mathrm{~nm}$.

Quantum efficiency shown in Figure 6 reveals a peak response of \% (70-90) and falls off in the range below (300 - 400) $\mathrm{nm}$ due to the recombination and absorption in the CIS and $\mathrm{ZnO}$.

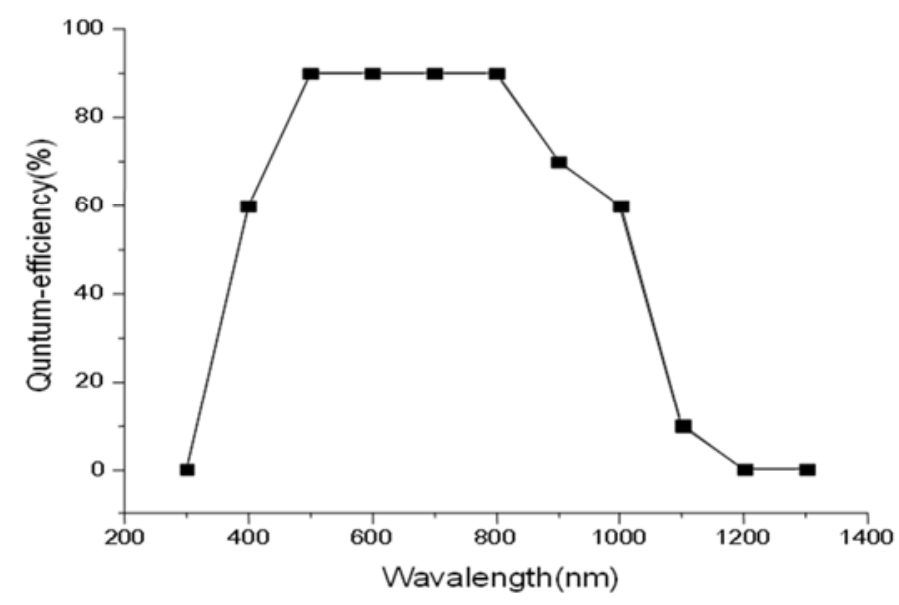

Figure 6. Quantum efficiency of $\mathrm{ZnO} / \mathrm{F} / \mathrm{ZnO} / \mathrm{CIS} / \mathrm{Mo}$ solar cell.

From EQE measurements, it is typically difficult to differentiate between recombination losses and optical losses. One possibility to identify recombination losses is to apply a bias voltage $\mathrm{V}$ to the solar cell during the EQE measurement. With this the SCR width W (V) increases or decreases depending on, if a reverse or a forward bias voltage is applied and the EQE changes accordingly as analyzed in literature [15].

\section{5. $C(V)$ Characteristics}

The capacitance-voltage measurements $(\mathrm{C}-\mathrm{V})$ are useful for obtaining a default concentration. The fault states can be studied by measuring the frequency of the junction complex admittance. The alternating voltage with the frequency $\mathrm{f}=\omega / 2 \pi$ is applied to the heterojunction or Schottky-contact. $\mathrm{C}-\mathrm{V}$ characteristics measurements are performed using the programs SCAPS. The following figure 7 presents the characteristic $\mathrm{C}=\mathrm{f}(\mathrm{V})$ for the photovoltaic cell, with the defects concentration equal to $10^{16} \mathrm{~cm}^{-3}$ at the absorber.

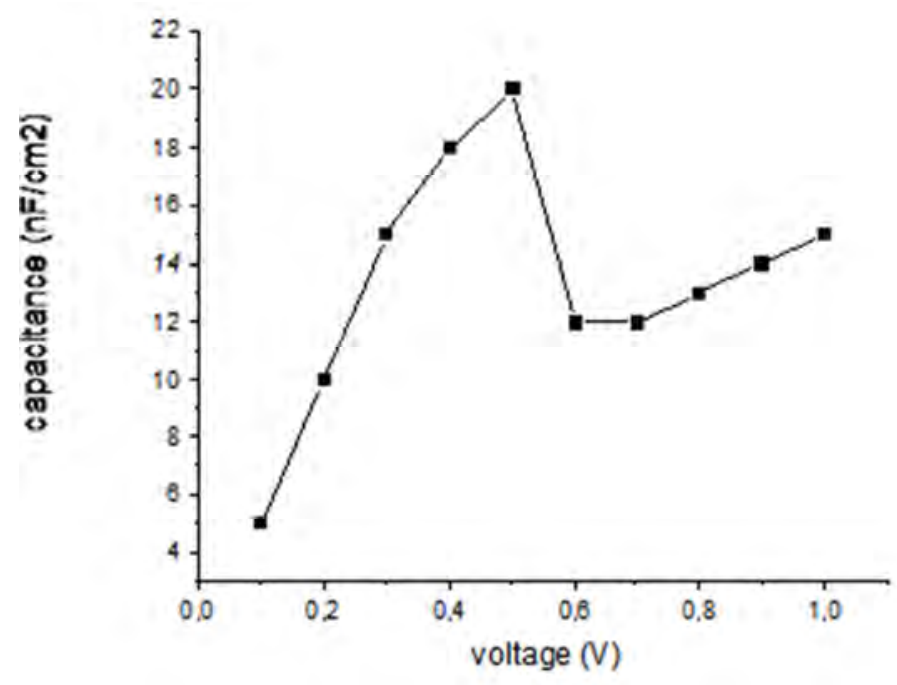

Figure 7. C-V characteristic for the cell $\mathrm{ZnO}: \mathrm{F} / \mathrm{ZnO} / \mathrm{CIS} / \mathrm{Mo}\left(f=10^{6} \mathrm{~Hz}\right)$. 
The picture generated electrons are captured and trapped in the volume of the absorber. This causes a decrease in the Fermi level for holes and yet increases the majority carriers' density and the conductivity. Inside $\mathrm{ZCE}$ of $\mathrm{CuInSe}_{2}$ the trapped electrons show a negative space charge. Therefore, the depth of ZCE decreases, thereby the junction capacity increases [16]. The results show that the best results regarding the cell CIS / $\mathrm{ZnO}$ with a stability of capacitance $\mathrm{C}=15 \mathrm{nF} / \mathrm{cm}^{2}$ and a short circuit voltage $\mathrm{Voc} \approx 0.6 \mathrm{~V}$. There has been a small increase of capacitance $\mathrm{C}$ value between $0.5 \mathrm{~V}$ and $0.6 \mathrm{~V}$.

\section{Conclusion}

These numerical simulation research aimed to provide a better understanding of how work solar cells wih $\mathrm{ZnO}$ buffer layer and $\mathrm{CuInSe}_{2}$ absorber. The thin film CIS solar cells performance are numerically simulated by using software SCAPS- 1D. Several parameters were taken into account. In particular, the band gap effect (the p-layer absorber CIS) and the doping concentration effect $(\mathrm{n}-\mathrm{ZnO})$ window layer were studied. It was noticed that the solar cell has heterojunction $\mathrm{ZnO}: \mathrm{F} / \mathrm{CIS}$ presented the best performance for the special values of the band gap (Eg) and the doping concentration for the $2000 \mathrm{~nm}$ thickness CIS absorber layer and $10 \mathrm{~nm}(30 \mathrm{~nm})$ for the $\mathrm{ZnO}(\mathrm{ZnO}: \mathrm{F})$ window layer. The optimized values were found: $\mathrm{Eg} \approx 1,20-1.30 \mathrm{eV}$ and $\mathrm{N}=1 \times 10^{16} \mathrm{~cm}^{-3}, \mathrm{~N}_{\mathrm{A}}=$ $10^{17}-10^{18} \mathrm{~cm}^{-3}$ for the bandwidth and concentration, respectively. These values have provided the best results for the conversion efficiency $(\eta)$.

According to our simulation results, the cell has the following characteristics: short circuit current $\mathrm{I}_{\mathrm{CC}} \approx 46-48$ $\mathrm{mA} / \mathrm{cm}^{2}$, the open circuit voltage $\mathrm{Voc}=0.550-0.565 \mathrm{~V}$ form factor $\mathrm{FF} \approx 82 \%$ and a yield conversion $\eta=20.74$ $22.23 \%$. The analysis of these results shows that the addition of zinc oxide doped with fluorine as an optical window improves efficiency by more than 5\%. It increases the short circuit current Jsc by $5 \%$ and the open circuit voltage Voc by $0.06 \mathrm{~V}$ compared to the CIS conventional junction.

\section{Acknowledgements}

The authors gratefully acknowledge to Dr. Marc Burgelman, University of Gent, Belgium, for providing the SCAPS simulation software.

\section{References}

[1] TRPV Working Group. (2014). International Technology Roadmap for Photovoltaic (ITRPV) 2013 Results.

[2] Osborne, M. (2013). First Solar hits cost reduction milestone.

[3] DOE Technical Report. (2012).

[4] Burgelman, M., Decock, K., Khelifi, S., \& Abass, A. (2013). Advanced electrical simulation of thin film solar cells. Thin Solid Films, 535, 296-301. doi:10.1016/j.tsf.2012.10.032
[5] Kanevce, A. (2007). Anticipated performance of $\mathrm{Cu}$ (In, Ga) $\mathrm{Se}_{2}$ solar cells in the thin-film limit (Doctoral dissertation, Colorado State University).

[6] Malm, U., Malmström, J., Platzer-Björkman, C., \& Stolt, L. (2005). Determination of dominant recombination paths in $\mathrm{Cu}$ (In, Ga)Se $\mathrm{Se}_{2}$ thin-film solar cells with ALD-ZnO buffer layers. Thin Solid Films, 480-481, 208-212.

doi:10.1016/j.tsf.2004.11.008

[7] Gloeckler, M., Sites, J. R., \& Metzger, W. K. (2005). Grainboundary recombination in $\mathrm{Cu}(\mathrm{In}, \mathrm{Ga}) \mathrm{Se}_{2}$ solar cells. Journal of Applied Physics, 98(11), 113704. doi:10.1063/1.2133906

[8] Gloecker, M. (2005). Device Physics of Cu (In, Ga)Se $\mathrm{Se}_{2}$ Thinfilm Solar Cells (Doctoral dissertation).

[9] Tala Ighil, R., Iratni, A., Arabi, N., Bensouici, F., \& Slimani, A. (2012, February). Effect of CdS Replacement by Cd-free buffer layer onto (CIS) solarcell. Paper presented at International Work Shop on Advanced Materials IWAM 2012, Ras Al Khaimah, United Arab Emirates.

[10] Montes-Monsalve, J., Morales-Acevedo, A., Bernal-Correa, R., \& Pulzara-Mora, A. (2016). Characterization of $\mathrm{CuInSe}_{2}$ thin films obtained by rf magnetron co-sputtering from $\mathrm{CuSe}$ and in targets. chalcogenide letters, 13(8), 381-388. Retrieved from http://www.chalcogen.ro/381_MontesMJI.pdf

[11] Guillen-Santiago, A., De la L. Olvera, M., Maldonado, A., Asomoza, R., \& Acosta, D. R. (2004). Electrical, structural and morphological properties of chemically sprayed F-doped $\mathrm{ZnO}$ films: effect of the ageing-time of the starting solution, solvent and substrate temperature. physica status solidi (a), 201(5), 952-959. doi:10.1002/pssa.200306727

[12] Lindahl, J., Keller, J., Donzel-Gargand, O., Szaniawski, P., Edoff, M., \& Törndahl, T. (2016). Deposition temperature induced conduction band changes in zinc tin oxide buffer layers for $\mathrm{Cu}(\mathrm{In}, \mathrm{Ga}) \mathrm{Se}_{2}$ solar cells. Solar Energy Materials and Solar Cells, 144, 684-690. doi:10.1016/j.solmat.2015.09.048

[13] Klinkert, T. (2015). Comprehension and optimisation of the co-evaporation deposition of $\mathrm{Cu}(\mathrm{In}, \mathrm{Ga}) \mathrm{Se}_{2}$ absorber layers for very high effciency thin film solar cells. Chemical Physics [physics.chem-ph] (Doctoral dissertation, Universite Pierre et Marie Curie - Paris VI).

[14] Sun, J., Nalla, V., Nguyen, M., Ren, Y., Chiam, S. Y., Wang, Y ... Wong, L. H. (2015). Effect of Zn (O, S) buffer layer thickness on charge carrier relaxation dynamics of $\mathrm{CuInSe}_{2}$ solar cell. Solar Energy, 115, 396-404. doi:10.1016/j.solener.2015.03.008

[15] Hegedus, S. S., \& Shafarman, W. N. (2004). Thin-film solar cells: device measurements and analysis. Progress in Photovoltaics: Research and Applications, 12(23), 155-176. doi:10.1002/pip.518

[16] Benosman, M., Bouchaour, M., Dujardin, F., Charles, J. P., \& Benyoucef, B. (2003). Le Rôle Du Mécanisme de Recombinaison sur Les Performances Photovoltaïques des Cellules Solaires de Type $\mathrm{Cu}(\mathrm{In}, \mathrm{Ga})\left(\mathrm{S}, \mathrm{Se}_{2}\right)$. Revue: Energie Renouvelable: ICPWE, 103-106. 